\title{
Ewolucja urządzeń zabezpieczenia socjalnego w Polsce oraz ich prawne kwalifikacje (szkic rozwoju)
} Ciniejszy szkic został pomyślany jako próba zarysowania rozwoju
form zabezpieczenia socjalnego w Polsce od fazy najwcześniejszej, datowanej na wiek XII, po czasy współczesne. W związku z badaniami nad niektórymi instytucjami zabezpieczenia socjalnego, w tzw. częściach historycznych tych opracowań wskazuje się nieraz na ich ewolucję. Brakuje natomiast ujęć ukazujących cały dotychczasowy rozwój urządzeń zabezpieczenia socjalnego.

W piśmiennictwie jest na ogół w użyciu termin „zabezpieczenie społeczne", a nie zawarte w tytule niniejszego szkicu określenie "zabezpieczenie socjalne”. Pojęcie „zabezpieczenie społeczne” wykształciło się w latach trzydziestych i czterdziestych XX w. w polityce społecznej i uzyskało szeroki kontekst międzynarodowy jako termin aktów prawnomiędzynarodowych i umów międzypaństwowych. Jego treściowa zawartość nie obejmuje zasadniczo sposobów zabezpieczenia socjalnego z okresów wcześniejszych. W niniejszym opracowaniu chciałbym ukazać cały proces rozwojowy urządzeń służących zaspokojeniu potrzeb bytowych człowieka w Polsce-zarówno sposobów najdawniejszych, jak i tych najnowszych, nie mieszczących się $\mathrm{w}$ ramach zabezpieczenia społecznego $\mathrm{w}$ przyjmowanym współcześnie rozumieniu.

Ze względu na charakter opracowania oraz jego ograniczone rozmiary zakres cytowania bogatego piśmiennictwa w interesującej nas materii musiał zostać mocno ograniczony.

1. Najwcześniejsza faza zorganizowanej działalności ludzkiej w interesującym nas zakresie na ziemiach polskich, datowana już na wiek XII, została określona mianem dobroczynności. Określenie to nawiązuje

* Prof. zw. dr hab., Zakład Prawa Pracy, Wydział Prawa, Administracji i Ekonomii Uniwersytetu Wrocławskiego. 
do motywów podejmowania działań pomocowych, którymi w Europie chrześcijańskiej było okazywanie miłosierdzia w stosunku do potrzebujących. Ich formą były indywidualne działania w postaci udzielania wsparcia (jałmużny), ale również pewne działania zorganizowane np. jako działające przy parafiach tzw. szpitale, stanowiące przytułki dla kalek i starców, hojnie nieraz obdarowywane przez panujących i możnowładców. Państwo w okresie średniowiecza pilnowało porządku publicznego, występowało $\mathrm{w}$ charakterze władzy policyjnej, m.in. reglamentując dozwolony sposób i zakres uprawiania żebractwa przez osoby pozbawione środków utrzymania, celem zapobieżenia kradzieżom, napadom i niepokojom społecznym. Uprawianie działalności dobroczynnej pozostawiono Kościołowi, klasztorom oraz osobom prywatnym. Liczba i rodzaje różnych stowarzyszeń religijnych, gromadzących również ludzi świeckich, zwłaszcza wszelakich bractw tworzonych nie tylko dla celów wspólnych modlitw, ale też wzajemnej pomocy i wspierania ubogich, na przestrzeni XVI i XVII w. wzrastała, przy czym działalność ich nadal polegała na udzielaniu indywidualnej pomocy oraz opiece nad ubogimi w miejscu zamieszkania, zakładaniu przytułków dla starców i kalek oraz sierot, które miały być kształcone w rzemiośle ${ }^{1}$. W późniejszych latach doszło do wzrostu ingerencji państwa w sprawy dobroczynności przez wzmocnienie nadzoru nad działalnością dobroczynną Kościołów, zakonów i osób prywatnych. Instrumentem prawnym nadzoru było zatwierdzanie fundacji i nadawanie statutów szpitalom (przytułkom) oraz polityka zwolnień instytucji dobroczynnych od podatków i innych powinności publicznych, a także podejmowanie prób uporządkowania finansowania działalności dobroczynnej, w szczególności szpitali (przytułków).

Powodzenie wysiłków w tych dziedzinach wymagało już istnienia administracji spraw dobroczynności. $Z$ jej tworzeniem wiąże się nowy etap rozwoju dobroczynności, określanej jako dobroczynność publiczna. Budowa administracji dobroczynności trwała przez wiele lat, począwszy od utworzenia Komisji Dobroczynnego Porządku (1768 r.), przez ustanowienie przez Sejm Czteroletni Komisji Szpitalnej, następnie komisji dobrego porządku, aż po rok 1817, kiedy postanowieniem Namiestnika Królestwa o Radach Szpitalnych określone zostały władze zobowiązane do zajmowania się sprawami dobroczynności oraz sformułowano zasady opieki nad ubogimi. Władze Królestwa Polskiego uczyniły ze sprawy budowy administracji dobroczynności jedno ze swych priorytetowych zadań. Według ustawy z 2 grudnia 1817 r. naczelne kierownictwo instytucjami dobroczynnymi należało do Rady Głównej Opiekuńczej, do działają-

${ }^{1}$ J. Zawadzki, Zasady opieki społecznej, Warszawa 1935, s. 19 i nast.; K. Stopka, Zasada subsydiarności w pomocy społecznej, Warszawa 2009. 
cych w terenie rad szczegółowych, a w parafiach do dozorów parafialnych. W tych ostatnich występowali łącznie przedstawiciele władzy świeckiej i kościelnej jako instytucje zarządzające domami schronienia dla starców i kalek oraz sprawujące opiekę nad ubogimi i sierotami w parafiach.

Ukaz (reskrypt) cara Mikołaja I z 18 lutego 1842 r. $^{2}$ rozbudował administrację dobroczynności, sprecyzował kompetencje poszczególnych jej organów oraz zasady udzielania wsparcia. Rada Główna Opiekuńcza, aczkolwiek usytuowana przy Komisji Spraw Wewnętrznych i Duchowych, zajmowała tam samodzielną pozycję („,niezależna od żadnego z iey Wydziałow" - art. 2). Zarząd szpitalami został powierzony radom opiekuńczym szczegółowym, natomiast zarząd domami schronienia należał do dozorów parafialnych. Te ostatnie miały zajmować się „wszelkiemi własnościami i funduszami domów schronienia”, a także ich organizacją. Istotne było sprecyzowanie zasad sprawowania opieki przez gminę. Między innymi zobowiązano dozory do objęcia opieką sierot i podrzutków urodzonych w parafii do dziewiątego roku życia oraz starców i osób niedołężnych należących do parafii, z czego jednak nie wynikało roszczenie o jej udzielenie. Biedni, którzy nie posiadali wymaganego okresu zamieszkania mogli być z gminy wydaleni; spory między gminami rozstrzygały rady parafialne ${ }^{3}$. Wyraźnie sformułowana została zasada subsydiarności przez obarczenie obowiązkami opieki w pierwszym rzędzie wszystkich krewnych lub powinowatych „na których z przepisów prawa Cywilnego spada obowiązek dania im przytułku i sposobu utrzymania”, ewentualnie - łożenia na ich utrzymanie $\mathrm{w}$ domach schronienia, jeżeli nie dają im utrzymania u siebie. Dozory parafialne miały prawo żądania od ubogiego, utrzymywanego kosztem parafii, podjęcia zatrudnienia odpowiadającego jego siłom względnie prawo do wyznaczenia ich do udzielania posługi Kościołowi lub też mogły „wynaymować ich mieszkańcom parafii za umówione wynadgrodzenie, na rzecz właściwego domu schronienia” (art. 51). Przepis ten uzupełniała ustawa z 1830 r. Prawo o włóczęgach, tułaczach $i$ żebrakach, przewidująca przekazywanie na podstawie wyroku sądowego wymienionych grup osób do publicznych instytutów pracy i przytułku na czas od jednego do trzech miesięcy z obowiązkiem świadczenia pracy. Powyższe, niepełne wyliczenie zasad organizacji i udzielania świadczeń nie obejmuje wyliczenia szerokiego rodzaju świadczeń i miało na celu jedynie przybliżenie obrazu dawnej dobroczynności, której niektóre zasady przetrwały do czasów współczesnych.

Reskrypt carski posługiwał się już terminem dobroczynność publiczna. W późniejszych regulacjach (1870 r.) oraz w piśmiennictwie termin

${ }^{2}$ Zbiór przepisów administracyjnych Królestwa Polskiego, cz. I, t. I, Warszawa 1866.

${ }^{3}$ A. Okolski, Wykład prawa administracyjnego oraz prawa administracyjnego obowiazujacego w Królestwie Polskiem, Warszawa 1882, t. II, s. 282. 
ten przyjął się na oznaczenie nowej fazy rozwoju działalności opiekuńczej. Regulacja prawna działalności opiekuńczej w stosunku do biednych była rozbudowana w licznych aktach prawnych. W systemie ówczesnego porządku prawnego stanowiła część prawa administracyjnego Królestwa Polskiego.

2. Kolejny etap w jej rozwoju stanowiła ustawa z 1 lutego $1923 \mathrm{r}$. o opiece społecznej ${ }^{4}$. Według art. 1 ustawy opieką społeczną jest zaspokajanie ze środków publicznych niezbędnych potrzeb życiowych osób, które trwale lub chwilowo własnymi środkami materialnymi bądź pracą uczynić tego nie mogą. Opieka społeczna przysługiwała subsydiarnie nie tylko w stosunku do własnych możliwości osoby potrzebującej, ale również wobec obowiązków pomocy spoczywających na podstawie przepisów prawa na innych osobach. Obywatele mieli prawo do trwałej opieki ze strony gminy po rocznym pobycie $w$ gminie. Nie przysługiwało im jednak roszczenie o udzielenie świadczeń. Obowiązki w zakresie wykonywania opieki spoczywały na gminach i na związkach komunalnych. Koszty opieki były pokrywane ze środków budżetowych gmin i związków komunalnych.

Od końca XIX w. rozwojowi dobroczynności, a następnie opieki społecznej, towarzyszyło kształtowanie się innego urządzenia zabezpieczenia socjalnego w postaci ubezpieczenia społecznego ${ }^{5}$.

Nie wydaje się celowe wchodzenie w tym miejscu w szczegóły dotyczące wprowadzania na ziemiach zaboru pruskiego oraz austriackiego poszczególnych rodzajów ubezpieczenia społecznego; co następowało od lat osiemdziesiątych XIX w. Na ziemiach zaboru rosyjskiego obok instytucji dobroczynności publicznej powstawały samorzutnie dobrowolne organizacje samopomocy pracowniczej, często wspomagane przez pracodawców, mających w tym własny interes, a w późniejszych okresach również przez państwo i samorządy. Ich stan finansowy był jednak zły ze względu na brak prawidłowych podstaw finansowych: wysokość świadczeń określono wysoko, składka była natomiast niska ; w sumie rozwiązania tam wprowadzane stanowiły mieszankę ubezpieczenia prywatnego i za-

${ }^{4}$ DzU RP, 1923, nr 92, poz. 726.

${ }^{5}$ Jego początków można upatrywać w Polsce w kasach górniczych, które rozwijały się autonomicznie od XVI w. Artykuł 58 „Ordunku Gornego”, wydanego w 1528 r. przez księcia opolskiego Jana przewidywał, że co sobotę, przy wypłacie sztygar lub sztychmistrz winien pobrać od pracujących w kopalni po dwa halerze i przekazać je do specjalnej kasy brackiej, której zarząd dysponował funduszami i przekazywał je na opiekę lekarską, szpitale i sierocińce, na wspieranie wdów lub sierot po śmierci górników; zob. J. Piernikarczyk, Pierwsza polska ustawa górnicza czyli „Ordunek Gorny”, wyd. fototypiczne, Opole 1996.

${ }^{6}$ K. Duch, Ubezpieczenie społeczne, Warszawa 1934, s. 12. 
opatrzenia z elementami dobroczynności. Pominiemy też detaliczny opis kształtowania się rodzimych ubezpieczeń społecznych po odzyskaniu przez Polskę niepodległości. Podkreślić natomiast należy pewne właściwości nowego systemu zabezpieczenia w postaci ubezpieczenia społecznego w relacji do dobroczynności i opieki społecznej. W szczególności dotyczy to jego cechy w postaci sposobu i zakresu działania oraz ukształtowanie pozycji prawnej jednostki. Stały się one podstawą do formułowania ocen na temat wzajemnego stosunku tych urządzeń i ich perspektyw rozwojowych. Podkreślano, że opieka społeczna, dawniej sprawowana w ramach dobroczynności przez osoby prywatne, miała indywidualistyczny charakter. Również później, jako działalność obowiązkowa władz, tj. jako dobroczynność publiczna, nie utraciła zasadniczo tego charakteru i nie była w stanie włączyć się w nurt przeobrażeń systemowych społeczeństwa7

Ubezpieczenia społeczne cechował duży dynamizm rozwojowy, widoczny $\mathrm{w}$ obejmowaniu przez nie zaspokojenia potrzeb $\mathrm{w}$ razie zaistnienia coraz szerszego kręgu ryzyk losowych. Nie wchodząc w szczegóły, $\mathrm{w}$ okresie międzywojennym ukształtowały się cztery rodzaje ubezpieczeń społecznych: ubezpieczenie chorobowe, ubezpieczenie wypadkowe, ubezpieczenie emerytalne i ubezpieczenie na wypadek bezrobocia. Liczba osób pobierających świadczenia ubezpieczeniowe była bardzo znaczna. Z końcem 1932 r. z tzw. ubezpieczeń długoterminowych (ubezpieczeń od wypadków i ubezpieczenia inwalidzkiego robotników), z ubezpieczenia emerytalnego pracowników umysłowych i specjalnego ubezpieczenia górników wypłacono 339000 rent. Z zasiłków chorobowych stale korzystało przeciętnie 40000 osób, a z zasiłków z tytułu bezrobocia przeciętnie ponad 100000 osób $^{8}$. Z tego punktu widzenia ubezpieczenie społeczne było zdolne do oddziaływania w skali masowej i mogło kształtować stosunki społeczne.

W ocenie K. Krzeczkowskiego oznaczało to kurczącą się społeczną rolę opieki społecznej w wymienionych przedziałach. Równocześnie konstrukcja ubezpieczenia społecznego, w którym w razie zaistnienia zdarzenia losowego automatycznie, z mocy prawa, powstawało prawo do świadczeń, miała tę niezaprzeczalną zaletę, że wydobywała świadczeniobiorcę z kręgu osób skazanych - ciągle jeszcze - na akt miłosierdzia. Wprawdzie uczynienie opieki społecznej obowiązkiem władz publicznych (gminy), nowe rodzaje świadczeń, mające na celu m.in. wyprowadzenie dotkniętych biedą z ich dotychczasowej sytuacji, poziom udzielanych świadczeń,

${ }^{7}$ K. Krzeczkowski w opracowaniu O trzech etapach opieki społecznej, [w:] idem, Polityka społeczna. Wybór pism z życiorysem i charakterystyka twórczości, Łódź 1947, s. 156. Zob. też K. Krzeczkowski, Uwagi nad drogami opieki społecznej, [w:] idem, Polityka społeczna. Wybór pism...

${ }^{8}$ Por. K. Duch, Ubezpieczenie społeczne..., s. 15. 
nieraz wyższych od świadczeń ubezpieczeniowych i brak ograniczeń czasowych $\mathrm{w}$ możliwości korzystania $\mathrm{z}$ nich wprowadziły opiekę $\mathrm{w}$ nowe stadium rozwojowe, ale nie zmieniało ogólnego wydźwięku działalności opiekuńczej. Cytowany autor ujmował to w ten sposób, że - w jego ocenie - dzieje obu instytucji wskazywały na zanikającą rolę opieki społecznej, a przynajmniej niektórych form tej opieki, gdy - odwrotnie - ubezpieczenia wykazywały niezwykłą prężność i siłę dynamiczną, co każe przypuszczać, że najbliższe czasy należą do tej formy zabezpieczenia społecznego 9

$\mathrm{Z}$ interesującego nas punktu widzenia rozwój urządzeń zabezpieczenia socjalnego w koncepcji K. Krzeczkowskiego przebiegał od prostych form samopomocy $\mathrm{w}$ ramach rodziny (rodu) poprzez dobroczynność prywatna, dobroczynność publiczna, opiekę społeczna, różne formy pomocy w ramach ubezpieczeń prywatnych do ubezpieczenia społecznego z perspektywą jego przekształcenia, łącznie z pozostałościami form wcześniejszych w system zabezpieczenia społecznego. Z kolei rozwój opieki społecznej to proces stałej redukcji opieki z perspektywą jej roztopienia się w systemie zabezpieczenia społecznego z pozostawieniem pewnych przydatnych form cząstkowych ${ }^{10}$.

Uprzedzając nieco dalsze uwagi należy stwierdzić, że historia nie potwierdziła przewidywań K. Krzeczkowskiego co do dalszych losów opieki społecznej. Nie dostrzegał on, że w dziedzinie opieki społecznej zachodziły dwa procesy. Jeden istotnie polegał na przejmowaniu od opieki społecznej (w późniejszym czasie - od pomocy społecznej) zaspokojenia niektórych ważnych potrzeb ludzkich. Niektóre rodzaje świadczeń czy też pewne rozwiązania organizacyjne, które wyrosły $w$ ramach dobroczynności publicznej bądź opieki społecznej były z zakresu tej opieki wyjmowane i następnie „lokowane”, z reguły w doskonalszej postaci, jako urządzenia należące do innych dziedzin. Nieraz następowało to w przeciągu stosunkowo krótkiego okresu, w innych przypadkach była to dłuższa ewolucja, polegająca na stopniowym oddalaniu się danego urządzenia od macierzystego pnia ${ }^{11}$. Równolegle do zjawiska „oddawania pól” przez opiekę (pomoc) społeczną postępował jednak drugi proces, poszerzania zakresu jej działania o nowe kierunki, do tego czasu nie objęte opieka, względnie takie, które ujawniły się jako następstwo rozwoju cywilizacyjnego. Niekiedy opieka (pomoc) społeczna przygotowywała jedynie grunt pod nowe, doskonalsze rozwiązania prawno-organizacyjne, innym razem ujawniała określone potrzeby i inicjowała sposoby ich zaspokojenia. Ponieważ rozmiar ujawnionych potrzeb z czasem przekraczał moż-

${ }^{9} \mathrm{~K}$. Krzeczkowski, O trzech etapach...

${ }^{10}$ Por. przyp. 7.

11 H. Szurgacz, Wstęp do prawa pomocy społecznej, Wrocław 1993, s. 15 i nast. oraz podane tam przykłady. 
liwości działania opieki (pomocy) społecznej, dochodziło do interwencji ustawodawczej, której efektem było przekazanie spraw innym instytucjom w zmodernizowanym już kształcie. Spełnianie przez opiekę (pomoc) społeczną opisanej funkcji, którą określiłem mianem funkcji pilotującej, jest jedną z najistotniejszych jej cech, tłumaczącą w dużym stopniu jej żywotność oraz przesądzającą o jej przydatności jako formie zabezpieczenia społecznego również w przyszłości ${ }^{12}$. Nie ma ona znaczenia historycznego, funkcję taką pełni współcześnie w dalszym ciągu pomoc społeczna.

W prawnej kwalifikacji wymienionych urządzeń zabezpieczenia socjalnego rozróżniano między opieką społeczną i ubezpieczeniem społecznym. Opieka społeczna była uznawana za część prawa administracyjnego. Ubezpieczenie społeczne uznawano natomiast za element składowy instytucji prawa pracy - ochrony pracy ${ }^{13}$.

3. W okresie II wojny światowej sytuacja w zakresie ubezpieczenia społecznego i opieki społecznej kształtowała się różnie na poszczególnych okupowanych przez Niemców terenach. Część ziem polskich została włączona do Rzeszy Niemieckiej z perspektywą uczynienia z nich obszaru niemieckiego, na którym Polacy mieli przebywać przejściowo w charakterze siły roboczej. Na terenach tych zostały zlikwidowane polskie ubezpieczenia społeczne. Stopniowo wprowadzono dla Polaków szczególny system bezroszczeniowych zapomóg (Unterstüzungen). W ocenie ówczesnych niemieckich komentatorów miał on być zbliżony do opieki społecznej. Polacy jednak płacili składki w tej samej co Niemcy wysokości, ale mogli korzystać ze świadczeń wielokrotnie niższych i to bez przyznania roszczenia o udzielenie świadczenia. Polskie instytucje opieki społecznej zostały zlikwidowane.

Z pozostałej części ziem polskich utworzono Generalne Gubernatorstwo, które w planach politycznych okupanta miało stanowić rezerwuar taniej siły roboczej. Utrzymana została polska organizacja ubezpieczenia społecznego, poddana jednak kierownictwu niemieckiemu nie mogła normalnie funkcjonować. Wygaszono natomiast roszczenia do wszystkich świadczeń z ubezpieczenia, wprowadzając w miejsce świadczeń zapomogi pieniężne, do których nie przysługiwały roszczenia prawne. Wysokość zapomóg $\mathrm{w}$ porównaniu ze świadczeniami ubezpieczeniowymi została ograniczona; dotyczyło to również pomocy leczniczej. W ograniczonych ramach, jakie pozostawił okupant, a także poza granicami ówczesnej

${ }^{12}$ H. Szurgacz, Wstęp do prawa pomocy..., s. 20; zob. też R. Babińska-Górecka, Funkcje pomocy społecznej, [w:] Z zagadnień prawa pracy i prawa socjalnego. Księga jubileuszowa Profesora Herberta Szurgacza, Warszawa 2011, red. Z. Kubot, T. Kuczyński, s. 372 i nast.

${ }^{13}$ K. Duch, Ubezpieczenie społeczne..., s. 13; zob. też M. Święcicki, Instytucje polskiego prawa pracy, Warszawa 1960. 
legalności, polski personel instytucji ubezpieczeniowych podejmował starania o zabezpieczenie minimalnych warunków bytu ludności ${ }^{14}$.

4. Po II wojnie światowej obowiązywały $\mathrm{w}$ Polsce $\mathrm{w}$ dalszym ciągu rozwiązania z okresu sprzed $1939 \mathrm{r}$. W związku z wprowadzaniem od lat pięćdziesiątych zasad ustroju socjalistycznego doszło do istotnych zmian w dotychczasowym systemie zabezpieczenia socjalnego. Kierunek zmian wynikał z przyjmowanych za wskazaniami radzieckimi ogólniejszych założeń budowy ustroju socjalistycznego. Jedno z nich zakładało, że zasadnicze przeobrażenia w sferze społecznej (równouprawnienie mężczyzn i kobiet, powszechne prawo do pracy) i gospodarczej (uspołecznienie środków produkcji) będą automatycznie prowadziły do rozwiązania charakterystycznych dla ustroju kapitalistycznego problemów socjalnych, szczególnie tych wynikających z bezrobocia i jego następstw.

Konsekwencje tego założenia najpierw dotknęły opiekę społeczna, uznawaną za urządzenie ustrojowo obce, związane z ustrojem kapitalistycznym. Przyjęto, że ten system świadczeniowy będzie działał w Polsce jedynie przejściowo i tylko w stosunku do $100 \%$ inwalidów i starców. Pomimo formalnego utrzymania w mocy ustawy z 1923 r. o opiece społecznej nie dostosowano jej do nowych warunków w zakresie ustroju administracji, nie powołano opiekunów społecznych, istotnego ogniwa systemu opiekuńczego, ograniczono aktywność organizacji charytatywnych i religijnych w opiece, aż po ich wyrugowanie z niektórych istotnych sfer działalności opiekuńczej.

Z kolei rozwijanie tzw. akcji socjalnej socjalistycznego zakładu pracy (zwanej później działalnością socjalną zakładu pracy), zgodnie z tezą o wyższości form kulturalnej i socjalno-bytowej obsługi ludności, miało przyczynić się do tego, że opieka społeczna stanie się w ogóle bezprzedmiotowa. Ekonomiści radzieccy (S. Strumilin) jeszcze w latach sześćdziesiątych głosili poglądy o społecznym odżywianiu i planowym zaopatrzeniu wielkich kolektywów robotniczych i potrzebie tworzenia komun produkcyjno-konsumpcyjnych ze wszystkimi urządzeniami socjalno-bytowymi i kulturalnymi, obsługującymi pracowników i członków ich rodzin. Początkowo ten typ działalności zakładu pracy był w polskim piśmiennictwie ekonomicznym nazywany działalnością opiekuńcza, konstruowano także opiekuńczą funkcję przedsiębiorstwa socjalistycznego ${ }^{15}$.

${ }_{14}$ Por. H. Szurgacz, Ubezpieczenia społeczne w latach okupacji hitlerowskiej 1939-1945, [w:] Rozwój ubezpieczeń społecznych w Polsce, ZN im. Ossolińskich, Wrocław 1991, s. 175 i nast.

${ }^{15}$ M. Pohorille, Spożycie zbiorowe i świadczenia społeczne, Warszawa 1975, s. 104 i nast. Zob. też H. Szurgacz, Zakładowa działalność socjalna. Zagadnienia prawne, [w:] Zakład pracy, red. J. Jończyk, Wrocław 1977. 
Działalność socjalna zakładów pracy była początkowo finansowana drogą dotacji budżetowych.

Wymienione urządzenie zabezpieczenia socjalnego zostało implementowane do systemu jako realizacja ideologicznych założeń socjalizmu, według radzieckich wskazań. Nie miało ono korzeni w rodzimej tradycji. Nie znaczy to, że np. w Polsce międzywojennej pracodawcy nie podejmowali działań na rzecz potrzeb socjalnych załóg swoich zakładów pracy, była to jednak działalność, która miała najpierw swoje źródła w opiece społecznej; później niektóre jej formy stały się elementem obowiązkowej ochrony pracy w stosunku do młodocianych i kobiet, wprowadzonej ustawą o ochronie pracy kobiet i młodocianych z $1924 \mathrm{r}$.

Od 1973 r., w związku z utworzeniem zakładowych funduszów socjalnego i mieszkaniowego, działalność socjalna była finansowana ze środków tych funduszów, które wchodziły w koszt działalności zakładu pracy. Zmieniły się zasady korzystania ze środków funduszu, co w sumie spowodowało, iż oddaliła się ona od pierwotnych założeń, przestając być elementem zabezpieczenia społecznego $\mathrm{w}$ dawniejszym rozumieniu.

Przebudowa ubezpieczeń społecznych dokonywała się pod wpływem tezy, że rozwój ustroju socjalistycznego w kierunku ustroju komunistycznego będzie prowadził do obumierania niektórych funkcji państwa, czemu musi towarzyszyć uspołecznienie wielu jego funkcji. Wydaje się, że dokonany podział ubezpieczeń społecznych, wzorowany na rozwiązaniach radzieckich, między pion związkowy (ubezpieczenie chorobowe i rodzinne) oraz pion administracji państwowej (Ministerstwo Pracy i Opieki Społecznej oraz prezydia wojewódzkich rad narodowych (ubezpieczenie emerytalne i wypadkowe), a w dalszej kolejności poddanie uprzednio autonomicznych instytucji ubezpieczeń społecznych pod kontrolę państwową i ich przekształcenie w urządzenia państwowe, dokonywało się pod wpływem wymienionej tezy.

W ogólniejszym teoretycznym ujęciu urządzeń zabezpieczenia socjalnego system z okresu lat pięćdziesiątych i sześćdziesiątych został określony mianem zabezpieczenia społecznego ${ }^{16}$. Terminem „zabezpieczenie społeczne" posługiwał się już K. Krzeczkowski w kontekście rozważań nad perspektywami opieki społecznej. Nie wchodząc w sporną sprawę, kiedy termin ten wszedł do języka prawnego ${ }^{17}$ wydaje się, że należy go wiązać ze znajdującą coraz szersze uznanie, wypracowaną w Anglii koncepcją tzw. planu Beveridge'a, zmierzającą do całościowego rozwiązywania występujących problemów socjalnych oraz zapobieżenia na przyszłość

16 J. Piotrowski, Zabezpieczenie społeczne. Problematyka i metody, Warszawa 1966.

17 M. Zieleniecki, Prawo do zabezpieczenia społecznego, "Gdańskie Studia Prawnicze” 2005, t. XIII, s. 18; J. Piotrowski, Zabezpieczenie społeczne..., s. 224 i nast. 
zjawiskom kryzysowym. Idea zabezpieczenia społecznego w celu usunięcia zjawiska niedostatku została przejęta do aktów międzynarodowych, jak ogłoszona przez Anglię, Stany Zjednoczone i Związek Radziecki Karta Atlantycka, do Powszechnej Deklaracji Praw Człowieka uchwalonej przez Zgromadzenie Ogólne ONZ, do konwencji MOP nr 102 o minimalnych normach zabezpieczenia społecznego, a także w przygotowanym przez V Światowy Kongres Związków Zawodowych w Moskwie w 1961 r. projekcie Karty Zabezpieczenia Społecznego ${ }^{18}$. Według J. Piotrowskiego zabezpieczenie społeczne obejmuje swoim zakresem ubezpieczenie społeczne w rozumieniu, $\mathrm{w}$ jakim występuje w aktach MOP (zwłaszcza w konwencji nr 102 o minimalnych normach zabezpieczenia społecznego z 1952 r.) oraz opiekę społeczna, stanowiąca potrzebny element zabezpieczenia społecznego. J. Piotrowski nie zaliczył natomiast do zabezpieczenia społecznego działalności socjalnej zakładu pracy, aczkolwiek w ujęciu autorów radzieckich, których przywołuje w monografii, stanowiła ona jedno z ogniw socjalistycznego zabezpieczenia społecznego. Według tego autora zabezpieczenie społeczne, jako działalność praktyczna, stanowi instytucjonalny system społecznego działania, w którym zostały wykorzystane instytucje i metody działania występujące $\mathrm{w}$ przeszłości, tj. ubezpieczenie społeczne i opieka społeczna.

5. Okres PRL od lat sześćdziesiątych nie stanowił już formacji, w której wszelkie dokonywane zmiany zdążały do ugruntowania socjalizmu w jego modelowej postaci. Obok regulacji zmierzających w tym kierun$\mathrm{ku}$, występowały zjawiska wprowadzania rozwiązań i instytucji będących $\mathrm{w}$ istocie zaprzeczeniem pierwotnych założeń ustroju socjalistycznego. Ich przyczyny były różne. Uznanie decyzją władz partyjnych w 1959 r. celowości istnienia i rozwijania opieki społecznej (pomocy społecznej) wynikało stąd, że nie sprawdziły się założenia o automatycznym pozytywnym działaniu zasadniczych przeobrażeń ustrojowych w sferze socjalnej. W dalszym ciągu istniały obszary niedostatku i biedy. W regulacji prawnej nie powrócono jednak do nie uchylonej ustawy o pomocy społecznej z 1923 r., opieka była regulowana "po nowemu” aktami instrukcyjnymi w postaci zarządzeń ministra zdrowia i opieki społecznej, kierowanymi do podległych ministrowi organów i ustanawiały dla nich pewne powinności ze względu na obywateli. Przyznawały one świadczeniobiorcom pozycję przedmiotu, a nie podmiotu prawa ${ }^{19}$.

${ }^{18}$ J. Piotrowski, Zabezpieczenie społeczne..., s. 29, 85; V Światowy Kongres Zwiazków Zawodowych, Moskwa 4-16 grudnia 1961 r. dokumenty, CRZZ, Warszawa 1962.

${ }_{19}$ Charakterystyczna była stylistyka tych aktów prawnych: „W celu zapewnienia gorącego podstawowego posiłku [...] ustala się co następuje...”; „W celu zapewnienia niezbędnej opieki osobom chorym, przebywającym w domu [...] organizuje się..." zob. 
System gospodarczy wymagał racjonalizacji, szczególnie w dziedzinie zatrudnienia. Podjęte działania zaowocowały bezrobociem, uznawanym dotychczas za zjawisko ustrojowo obce i zrodziły konieczność wprowadzenia w miejsce zlikwidowanego ubezpieczenia na wypadek bezrobocia zasiłków dla osób czasowo pozostających bez pracy, które były ukryte najpierw pośród zadań pomocy społecznej, następnie w funduszu aktywizacji zawodowej (1974), a dopiero później zostały rozbudowane w ustawie z 1983 r. o Państwowym Funduszu Aktywizacji Zawodowej.

W Konstytucji z 1952 r. art. 70 przewidywał, że podstawowym elementem urzeczywistniania obywatelskiego prawa do ochrony zdrowia oraz pomocy w chorobie i niezdolności do pracy jest rozwój ubezpieczenia społecznego robotników i pracowników umysłowych. To podmiotowe ograniczenie było trudne do utrzymania w warunkach potrzebnego przyspieszenia rozwoju gospodarczego i pobudzenia aktywności społecznej. Kolejno wprowadzono ubezpieczenie społeczne rzemieślników (1972), zaczątki ubezpieczenia społecznego osób wykonujących działalność twórczą (1973), objęto ubezpieczeniem społecznym osoby świadczące pracę na podstawie umów agencyjnych lub zlecenia (1975). Zmieniony w 1976 r. art. 70 Konstytucji nie przewidywał już wymienionego ograniczenia, co sprzyjało dalszemu rozszerzeniu ubezpieczenia społecznego w późniejszych latach (1978 - rolnicy, 1989 r. - duchowni). Warto dodać, że system, który się ukształtował, odbiegał od koncepcji zabezpieczenia społecznego Światowego Kongresu Związków Zawodowych z 1961 r. pod tym względem, że ten zakładał, iż zabezpieczenie społeczne stanowi podstawowe prawo klasy robotniczej.

Idea zabezpieczenia społecznego znalazła wyraz w teoretycznej koncepcji prawa zabezpieczenia społecznego Cz. Jackowiaka. Jego zdaniem nowe trendy rozwojowe $\mathrm{w}$ ubezpieczeniu społecznym uzasadniały tezę o wyodrębnianiu się prawa zabezpieczenia społecznego, rozumianego jako system gwarancji i środków służących zaspokojeniu społecznie usprawiedliwionych potrzeb obywateli, którzy utracili lub doznali ograniczenia zdolności do pracy albo zostali obciążeni nadmiernie kosztami utrzymania rodziny, jako samodzielnej gałęzi prawa. W systemie tym należałoby wyodrębnić podsystem pracowniczego zabezpieczenia społecznego. Zabezpieczenie społeczne jest realizowane za pomocą trzech technik (form): ubezpieczenia społecznego, zaopatrzenia społecznego i pomocy społecznej. Kryteriami ich wyróżnienia są technika finansowania świadczeń, źródło uprawnień oraz charakter uprawnieńn ${ }^{20}$. Nową formą (techniką) zaopatrzenia wyróżnioną przez autora było zaopatrzenie społeczne.

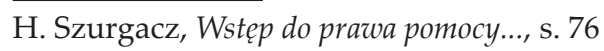

${ }^{20}$ Cz. Jackowiak, W. Jaśkiewicz, W. Piotrowski, Prawo pracy w zarysie, Poznań 1970; także wydanie z 1980 r. 
Cechą odróżniającą zaopatrzenie od ubezpieczenia było jego finansowanie z budżetu, a nie ze składek i w konsekwencji brak uzależnienia prawa do świadczenia od opłacania składek.

Koncepcja ta nie została powszechnie przyjęta. Jej krytycy wskazywali, że wyodrębnienie $\mathrm{w}$ ramach systemu prawa nowej gałęzi zwanej prawem zabezpieczenia społecznego jest przedwczesne ze względu na brak ukształtowanych zasad ogólnych, głębokie wewnętrzne zróżnicowanie części składowych prawa zabezpieczenia społecznego i niejednolitość metody regulacji prawnej. Zabezpieczenie społeczne może być ujmowane co najwyżej jako pojęcie zbiorcze z zakresu języka prawnego i prawniczego, służące określeniu systemu urządzeń bądź technik, mających na celu ochronę obywateli przed skutkami niebezpieczeństw zagrażających ich życiu i zdrowiu oraz podstawom egzystencji ${ }^{21}$.

Wychodząc z innych przesłanek, mianowicie od przeważającej roli ubezpieczenia społecznego jako sposobu zabezpieczenia potrzeb ludzkich, mając na uwadze jego tendencje rozwojowe $\mathrm{w}$ zakresie podmiotowym i przedmiotowym oraz z wykształconej regulacji prawnej W. Szubert skoncentrował swoją uwagę na ubezpieczeniu społecznym i jego prawnych aspektach. W jego ujęciu ubezpieczenie społeczne to przede wszystkim określony system świadczeń, gdyż to one stanowią cel i rację bytu tej instytucji. Podstawową kategorią teoretyczną są potrzeby i wyodrębniane, z uwagi na różne przyczyny i okoliczności ich zaistnienia, poszczególne rodzaje ryzyk (zdarzeń) ubezpieczeniowych, decydujących o zróżnicowaniu świadczeń ubezpieczenia społecznego. Prawo ubezpieczenia społecznego cechuje ustawowa gwarancja świadczeń, ich związek z praca, roszczeniowość, losowy charakter zaspokajanych potrzeb, spełnianie świadczeń przez wyspecjalizowane instytucje oraz rozłożenie ciężaru świadczeń, przynajmniej pośrednio, na zbiorowość osób do nich uprawnionych.

W tym ujęciu opieka społeczna pozostawała poza ubezpieczeniem społecznym. Wprawdzie, jak zauważa autor, w rozwoju ubezpieczenia społecznego i opieki społecznej można stwierdzić pewne złagodzenie występujących między nimi różnic (typizacja świadczeń opieki społecznej, wzmocnienie pozycji prawnej osób korzystających z tych świadczeń przez możliwość kontroli nad legalnością podejmowanych decyzji), niemniej jednak, mimo tego zbliżenia, brak roszczeniowości, brak związku z pracą i udzielanie świadczeń z tytułu obowiązków opiekuńczych obciążających lokalne organy administracji, nie pozwalają na włączenie opieki do ubezpieczenia społecznego. Poza ubezpieczeniem społecznym pozostawała w tej koncepcji również działalność socjalna zakładu pracy, w któ-

${ }^{21}$ W. Szubert, O charakterze prawnym ubezpieczenia społecznego, „Praca i Zabezpieczenie Społeczne" 1972, z. 3; L. Kaczyński, Pojęcie zabezpieczenia społecznego i kryteria rozróżnienia jego technik, „Praca i Zabezpieczenie Społeczne” 1986, z. 5-6. 
rej udzielane świadczenia wprawdzie mają związek z praca, ale brak im cechy roszczeniowości, ponieważ są przyznawane $\mathrm{w}$ ramach rozporządzalnych środków, na zasadzie preferencji, uwzględniających sytuację materialna i rodzinną poszczególnych pracowników. W zakresie ubezpieczenia społecznego nie mieściły się również systemy świadczeń dla funkcjonariuszy służb zbrojnych oraz inwalidów wojennych i wojskowych z uwagi na szczególny tytuł uprawnień, jakim w przypadku tych osób jest służba, a nie praca, oraz ze względu na brak jakiegokolwiek udziału uprawnionych w ponoszeniu kosztów świadczeń.

W. Szubert dostrzegał pojawienie się w systemie urządzeń odbiegających od klasycznych form ubezpieczenia społecznego, związanych z rozwijaniem profilaktyki i działalności zmierzającej do usuwania skutków ujemnych zdarzeń reaktywacja inwalidów) oraz nowych ryzyk, związanych z ruchem pojazdów mechanicznych, zanieczyszczeniem wód i powietrza. Oznaczało to zarazem poszerzenie pojęcia zabezpieczenia społecznego, które zyskało w związku z tym szerszy zakres, obejmując ogół środków podejmowanych w celu ochrony człowieka przed skutkami niebezpieczeństw zagrażających jego życiu i zdrowiu czy podstawom egzystencji. Jednak, jak wskazywał autor, ubezpieczenie społeczne pracowników i ich rodzin nadal pozostaje zasadniczym członem tak szeroko zakrojonego systemu ${ }^{22}$.

Odmiennie zakres przedmiotowy i podmiotowy ubezpieczenia społecznego konstruował J. Jończyk, według którego system opieki społecznej należy zaliczyć do ubezpieczenia społecznego w szerokim znaczeniu ${ }^{23}$. Autor wskazywał, że w toku ewolucji opieka społeczna (pomoc społeczna) upodobniała się pod względem prawnym do ubezpieczenia społecznego - ze względu na typizację niektórych świadczeń i procesową ochronę uprawnień z jednej strony, z drugiej zaś strony samo ubezpieczenie społeczne zmieniło się, wykazując w prawie materialnym i procesowym coraz większy margines uznaniowości, charakterystyczny dla opieki społecznej. Pomiędzy tymi systemami świadczeniowymi istnieje również związek funkcjonalny, w którym opieka społeczna występuje jako instytucja alternatywna bądź komplementarna.

6. Transformacja ustrojowa w Polsce formalnie została dokonana art. 1 znowelizowanej ustawą z 29 grudnia 1989 r. Konstytucji z 1952 r., stwierdzającym, że Rzeczpospolita jest demokratycznym państwem prawnym. Tym samym został uruchomiony proces niezbędnych przekształceń

${ }^{22}$ O charakterze prawnym ubezpieczenia społecznego, „Praca i Zabezpieczenie Społeczne” 1972, nr 3.

${ }^{23}$ Przedmiot prawa ubezpieczenia społecznego, [w:] Problemy ubezpieczenia społecznego, Wrocław 1988, s. 5 i nast. 
$\mathrm{w}$ wielu dziedzinach, również $\mathrm{w}$ zakresie zabezpieczenia socjalnego. Transformacja dokonywała się w warunkach głębokiego kryzysu gospodarczego. Prawu socjalnemu przypadła w tych warunkach rola instrumentu asekurującego wprowadzanie niezbędnych reform gospodarczych, które, zwłaszcza w pierwszej fazie ich stosowania, przyniosły dalsze pogorszenie położenia ludności. Do przedsięwzięć tych należało m.in. wielokrotne podwyższanie minimalnej emerytury, zmiana zasad waloryzacji, wprowadzenie wcześniejszych emerytur, świadczeń z tytułu bezrobocia, dodatków mieszkaniowych. Nie wchodząc w szczegóły poszczególnych doraźnych przedsięwzięć legislacyjnych i ich skutków, nie zawsze korzystnych dla systemu ubezpieczenia społecznego, zwrócimy uwagę na niektóre rozwiązania i procesy o charakterze bardziej trwałym.

Niewątpliwie należała do nich ustawa z 29 listopada 1990 r. o pomocy społecznej. Ustawa oznaczała jakościową zmianę w dotychczasowej opiece społecznej, której wyrazem była nie tylko nowa nazwa, ale zasadnicze zmiany w takich podstawowych elementach pomocy społecznej, jak pozycja prawna świadczeniobiorcy, przez jego upodmiotowienie i przyznanie mu roszczenia prawnego o udzielenie niektórych świadczeń tej pomocy, wzbogacenie rodzajów świadczeń, wzmocnienie organizacyjne pomocy, wprowadzenie podmiotów niepublicznych jako ważnego elementu systemu pomocy społecznej. W sumie ustawa potwierdziła rolę pomocy społecznej jako ważnego elementu systemu zabezpieczenia socjalnego.

Dla tej fazy rozwoju urządzeń zabezpieczenia socjalnego znamienne było wprowadzanie nowych systemów świadczeniowych. Niektóre z nich stanowiły produkt dłuższego rozwoju, ale ich wprowadzenie jako trwałego elementu zabezpieczenia socjalnego nie było wcześniej możliwe ze względu na pryncypia ustrojowe socjalizmu, względnie z powodów politycznych. Do tych pierwszych należały świadczenia na wypadek bezrobocia, które podlegały długiej ewolucji zanim ustabilizowały się w ustawie o zatrudnieniu i przeciwdziałaniu bezrobociu (1994). Do tych drugich należały np. świadczenia odszkodowawcze dla osób deportowanych do pracy przymusowej oraz osadzonych w obozach pracy przez III Rzeszę i ZSRR oraz z tytułu pracy przymusowej żołnierzy w kopalniach węgla, kamieniołomach i zakładach wydobycia rud uranu. Bardziej zasadnicze znaczenie miały regulacje $\mathrm{w}$ postaci ustawy o funduszu alimentacyjnym (1991), o zasiłkach rodzinnych i pielęgnacyjnych (1994) oraz o najmie lokali i dodatkach mieszkaniowych (1994), wprowadzające nowe rodzaje świadczeń, różnych od świadczeń z ubezpieczenia społecznego, zaopatrzenia i pomocy społecznej.

Cechą charakterystyczną systemu świadczeniowego, jaki kształtował się w nowych warunkach, było wspomniane już w związku z pomocą społeczną wzbogacenie rodzajów świadczeń przysługujących $\mathrm{w}$ razie 
zaistnienia określonego ryzyka socjalnego. Dalszych przykładów potwierdzających to zjawisko dostarczają przepisy regulujące świadczenia przysługujące $\mathrm{w}$ razie bezrobocia. Wystąpiło ono również, choć może w mniejszym jeszcze nasileniu, w ubezpieczeniu społecznym, np. w ubezpieczeniu rentowym i ubezpieczeniu chorobowym.

Zmieniony stan prawny skłaniał do refleksji nad charakterem przeobrażającego się systemu zabezpieczenia socjalnego. W opinii niektórych autorów oddalił się on od dotychczasowego modelu zabezpieczenia społecznego, charakteryzowanego jako triada trzech systemów świadczeniowych: ubezpieczenia społecznego, zaopatrzenia społecznego i opieki (pomocy) społecznej. Wynikało to stąd, że pojawiły się nowe rodzaje świadczeń, których cechy prawne nie pozwalały na ich zakwalifikowanie do dotychczasowych systemów świadczeniowych. Chodziło zwłaszcza o rodzaje świadczeń określanych jako świadczenia wsparcia (socjalnego) oraz świadczenia odszkodowania socjalnego. W konsekwencji został sformułowany postulat zastąpienia pojęcia prawa zabezpieczenia społecznego nowym terminem - prawa socjalnego, otwartym na zmiany dokonujące się w systemach świadczeniowych ${ }^{24}$.

Krytycznie do tych propozycji odniósł się J. Jończyk ${ }^{25}$ zarzucając, że termin "prawo socjalne” jest wieloznaczny, istnieją trudności z rozróżnieniem pojęć „sspołeczne” i „socjalne”, skutkiem czego termin ten ma małą wartość operatywną. Ponadto określenie "prawo socjalne" - zdaniem tego autora - jest związane z ideologią „państwa socjalnego” i teorią zaspokajania przez państwo potrzeb obywateli, tj. ma wyraźny kontekst ideologiczny.

J. Jończyk odstąpił następnie od koncepcji prawa ubezpieczenia społecznego sensu largo i przedstawił inną, rozwiniętą koncepcję prawa zabezpieczenia społecznego jako odrębnej gałęzi prawa ${ }^{26}$. Prawo to znajduje swoje zakotwiczenie w Konstytucji, która w art. 67 przewiduje wprost prawo do zabezpieczenia społecznego obywateli w razie niezdolności do pracy ze względu na chorobę lub inwalidztwo oraz po osiągnięciu wieku

${ }^{24}$ Por. referat W. Piotrowskiego, Prawo socjalne jako instrument realizacji polityki społecznej, wygłoszony na konferencji naukowej w Poznaniu w 1990 r. oraz referaty A. Chobota, A. Kijowskiego i H. Szurgacza wygłoszone na tej konferencji; materiały z konferencji nie zostały opublikowane. Por. też H. Szurgacz, Wstęp do prawa pomocy społecznej..., s. 75 i nast. Zob. też późniejsze opracowanie D. Lach, Pojęcie zabezpieczenia społecznego a przedmiot prawa socjalnego, [w:] Problemy zatrudnienia we wspótczesnym ustroju pracy, Księa Jubileuszowa na 55-lecie pracy naukowej i dydaktycznej Profesora Włodzimierza Piotrowskiego, red. Z. Niedbała, M. Skąpski, Poznań 2009.

25 Por. Przyczynek do koncepcji prawa ubezpieczenia społecznego, [w:] Studia z prawa pracy. 50-lecie działalności naukowej Prof. Dra Wactawa Szuberta, Łódź 1998.

${ }^{26}$ Prawo zabezpieczenia społecznego. Ubezpieczenia społeczne $i$ zdrowotne, bezrobocie i pomoc społeczna, Zakamycze, Kraków 2001; zob. też wydania z 2003 i 2006 r. 
emerytalnego, a także dla obywateli pozostających bez pracy nie z własnej woli i nie mających innych środków utrzymania. Termin "zabezpieczenie” oznacza przy tym - zdaniem autora - ochronę prawną i gwarancję bezpieczeństwa na wypadek określonego zagrożenia, przymiotnik „społeczne” z kolei odnosi się do rodzaju zagrożenia dotyczącego człowieka i zagrożenia grupy osób, jak i do wspólnego wysiłku tej społeczności, podejmowanego w celu zmniejszenia tego zagrożenia i łagodzenia jego skutków. Z tym łączy się element wspólnoty interesu i solidarnego współdziałania zagrożonej grupy osób ${ }^{27}$.

Prawo zabezpieczenia społecznego jest w tym ujęciu systemem ustawowych gwarancji i świadczeń na wypadek ziszczenia się socjalnego ryzyka. Pojęcie socjalnego ryzyka autor rozumie szeroko jako obejmujące nie tylko klasyczne ryzyka ubezpieczenia społecznego, ale również ryzyko niedostatecznego dochodu w rodzinie, ryzyko trudnych sytuacji życiowych ${ }^{28}$. Umożliwiło to objęcie pojęciem zabezpieczenia społecznego szerszego kręgu sytuacji socjalnych (ryzyk socjalnych), które dotychczas pozostawały poza ubezpieczeniem społecznym. Równocześnie, dostrzegając różnice w cechach systemów świadczeniowych służących zabezpieczeniu tych ryzyk w porównaniu z dotychczasowymi, autor kwalifikuje je jako należące bądź to do pomocniczej części zabezpieczenia społecznego (świadczenia z tytułu bezrobocia, świadczenia rodzinne), bądź też jako specyficzne, względnie łagodniejsze postacie innych „ustabilizowanych" ryzyk (renta socjalna, dodatki mieszkaniowe w przypadku ryzyka trudnych sytuacji życiowych).

7. Pomijając zmiany zachodzące $w$ kolejnych latach $w$ dotychczasowych systemach świadczeniowych (np. zmiany w ubezpieczeniu rentowo-inwalidzkim, w zabezpieczeniu na wypadek bezrobocia, w pomocy społecznej, w organizacji i finansowaniu ubezpieczenia społecznego), nadal postępował proces wzbogacania zabezpieczenia socjalnego o nowe rodzaje świadczeń. Dotyczyło to zwłaszcza dwu rodzajów wyróżnianych już wówczas w piśmiennictwie świadczeń, określanych jako świadczenia wsparcia socjalnego oraz świadczenia odszkodowania socjalnego.

Współcześnie do świadczeń socjalnego wsparcia zalicza się zasiłki rodzinne i dodatki do zasiłków rodzinnych, jednorazowe zapomogi z tytułu urodzenia dziecka, świadczenia z funduszu alimentacyjnego, pomoc mieszkaniowa pomoc dla osób opuszczających pieczę zastępcza, pomoc na wyrównanie szans edukacyjnych. Zdaniem M. Lewandowicz-Machnikowskiej regulacja prawna tych świadczeń stanowi odrębny dział prawa $\mathrm{w}$ ramach gałęzi prawa, którą jest prawo socjalne ${ }^{29}$.

${ }^{27}$ Ibidem, wydanie z 2006 r., s. 9.

${ }^{28}$ Ibidem, s. 22.

${ }^{29}$ Regulacja prawna socjalnego wsparcia dla osób o niskich dochodach, Wrocław 2013, seria e. Monografie. 
Według M. Lewandowicz-Machnikowskiej prawo socjalne ma swoje oparcie w Konstytucji, jednak w odróżnieniu od dotychczasowych ujęć, nie tylko w przepisie art. 70, ale w jej wszystkich przepisach dotyczących praw socjalnych. Autorka wyróżnia prawo socjalne w znaczeniu szerokim, obejmujące regulacje prawne dotyczące realizacji przez ustawodawcę wyrażonych w Konstytucji praw socjalnych oraz prawo socjalne w znaczeniu wąskim, obejmujące tylko te prawa socjalne, z których realizacji wynika prawo do świadczeń. Należą do nich prawo ubezpieczenia społecznego (emerytalnego, rentowego, chorobowego i wypadkowego), prawo do świadczeń opieki zdrowotnej, prawo zaopatrzenia społecznego, prawo promocji zatrudnienia, prawo rehabilitacji i zatrudnienia osób niepełnosprawnych, prawo odszkodowań socjalnych, prawo świadczeń pomocy społecznej oraz prawo świadczeń socjalnego wsparcia. Świadczenia wparcia socjalnego cechują się tym, że nie zastępują dochodu pracy, lecz uzupełniają te dochody, nie mają charakteru ekwiwalentnego, to znaczy nie są odpłata, np. za składkę, nie mają kompensować żadnego uszczerb$\mathrm{ku}, \mathrm{z}$ założenia nie są adresowane do najuboższych i ich podstawowym zadaniem nie jest zwalczanie ubóstwa, ale zaspokojenie pewnych szczególnych potrzeb ${ }^{30}$.

Również grupa świadczeń określanych jako świadczenia socjalnego odszkodowania uległa poszerzeniu. O ile początkowo ograniczała się do świadczeń dla inwalidów wojennych i wojskowych, dla kombatantów oraz osób będących ofiarami represji wojennych i lat powojennych, czyli do wyrównywania szkód związanych z II wojną światową i okresem powojennym, z czasem uległa poszerzeniu o świadczenia dla rodzin ofiar wystąpień wolnościowych w latach 1956-1989 oraz dla osób internowanych. Poza ta grupą świadczeń, którą ze względu na okoliczności uzasadniające ich przyznanie można określić jako mające związek ze zdarzeniami historycznymi, istnieje i ulega poszerzeniu grupa świadczeń wynikających z aktualnych zdarzeń, takich jak świadczenia dla ofiar wypadków zaistniałych w szczególnych okolicznościach, świadczenia dla osób udzielających pomocy organom (instytucjom) państwowym, kompensata dla ofiar przestępstw, świadczenia dla weteranów poszkodowanych w działaniach poza granicami państwa i ostatnio (2011) - związanych z powodziami (zasiłek powodziowy).

Termin „odszkodowanie socjalne" nie występuje w języku aktów normatywnych, jest to termin języka prawnego, współcześnie w coraz szerszym użyciu w piśmiennictwie. Kategoria świadczeń odszkodowania socjalnego nie znalazła do tej pory całościowego opracowania, analiza objęła zaopatrzenia z tytułu wypadków w szczególnych okolicznościach oraz

${ }^{30}$ Ibidem, s. 38, 39. 
państwową kompensatę dla ofiar przestępstw ${ }^{31}$. Pierwszy rodzaj świadczeń wykazuje istotne różnice w stosunku do ubezpieczeń społecznych (m.in. pozazawodowy charakter wypadków, brak obowiązku odprowadzania składek), w stosunku do pomocy społecznej (brak zasady subsydiarności świadczeń, brak ustalania konkretnych zindywidualizowanych potrzeb, brak elementu uzupełnienia niedostatku w dochodzie), a także zaopatrzenia społecznego (m.in. szczególny, swoisty tytuł uprawnienia do świadczeń). Z kolei państwowa kompensata dla ofiar przestępstw nie realizuje zadań prewencyjno-wychowawczych przypisywanych naprawieniu szkody $\mathrm{w}$ prawie karnym, ma natomiast formę odszkodowania pełniącego funkcję socjalna, jest ukierunkowana na potrzeby i sytuację bytową uprawnionego, ale zasady jej udzielania (ograniczony zakres badania „potrzeby) wykluczają możliwość jej kwalifikowania jako świadczenia z pomocy społecznej, a ze względu na metodę finansowania - ze środków budżetu państwa - nie jest świadczeniem ubezpieczeniowym, co nie wyklucza ujmowania jej jako świadczenia z zakresu zabezpieczenia społecznego, wykraczającego jednak poza tradycyjnie wyodrębniane systemy świadczeniowe zabezpieczenia społecznego. W uogólniającej konkluzji autorka ocenia, że odszkodowanie socjalne łączy się z koncepcją prawa socjalnego, a nie prawa zabezpieczenia społecznego.

8. Niniejszy szkic pozwolił ukazać dużą dynamikę rozwojową urządzeń zabezpieczenia socjalnego w Polsce. Ewolucja ta nie miała charakteru linearnego, tj. nie przebiegała po linii rozwoju i doskonalenia jednego, historycznie najwcześniejszego urządzenia, lecz po linii uzupełniania dawnego sposobu zabezpieczenia o urządzenia nowe, o lepsze urządzenia, które przejmowały część zadań w zakresie zabezpieczenia socjalnego, nie pozbawiając znaczenia urządzeń dawniejszych; te nowe również ewoluowały $\mathrm{w}$ procesie dłuższego rozwoju. W sumie współcześnie ukształtował się złożony system urządzeń socjalnych, dążących do osiągnięcia wspólnego celu zabezpieczenia potrzeb socjalnych człowieka. Wraz z postępem cywilizacyjnym zakres i rodzaj potrzeb, uznanych za społecznie usprawiedliwione i wymagających zaspokojenia, zmieniały się, w sumie jednak $\mathrm{w}$ kierunku ich poszerzania. Warto w tym miejscu wskazać na podjęte niedawno prace parlamentarne nad wprowadzeniem w Polsce instytucji odgrywającej rolę podobną do ubezpieczenia pielęgnacyjnego, istniejącego od dość dawna w niektórych krajach Europy Zachodniej, a także poza Europą; wersja robocza odpowiedniego projektu polskiej

${ }^{31}$ Por. K. Stopka, Charakter prawny zaopatrzenia z tytułu wypadków w szczególnych okolicznościach, „Państwo i Prawo” 2011, nr 9; eadem, Uwagi na temat charakteru prawnego państwowej kompensaty dla ofiar przestępstw, „Państwo i Prawo” 2014, nr 7. 
ustawy nosi nazwę „ustawy o pomocy osobom niesamodzielnym” i określa zasady przyznawania świadczeń z tytułu niesamodzielności oraz inne formy pomocy osobom niesamodzielnym i ich bliskim.

Regulacja prawna poszczególnych urządzeń zabezpieczenia socjalnego, w konsekwencji także ich prawna kwalifikacja oraz kwalifikacja prawna całości ukształtowanego w danym czasie systemu, również podlegały zmianom. Na przykład dobroczynność publiczna przekształciła się w opiekę społeczna, ta zaś w pomoc społeczną. Nie była to jedynie zmiana terminologii, ale $\mathrm{u}$ podstaw zmian nazwy leżały głębsze przyczyny w postaci zmiany charakteru prawnego instytucji. Przekształceniom podlega również dawniej jednolite ubezpieczenie społeczne, czego wyrazem jest choćby wyodrębnienie ubezpieczenia zdrowotnego i w konsekwencji operowanie liczbą mnogą „ubezpieczeń społecznych”. Wydaje się zresztą, że odnotowana zmiana nie kończy procesu wewnętrznych przekształceń ubezpieczenia $\mathrm{w}$ zakresie szeregu jego elementów konstrukcyjnych, na co ostatnio została zwrócona uwaga w piśmiennictwie ${ }^{32}$. Między innymi dawna jednorodna wspólnota ryzyka, w związku z obejmowaniem ubezpieczeniem społecznym coraz szerszych warstw społecznych, bez względu na ich związek z pracą, przestała istnieć. Podobnie w związku $\mathrm{z}$ finansowaniem składek z budżetu państwa (osoby na urlopach wychowawczych, osoby pobierające zasiłek macierzyński, osoby niepracujące pobierające zasiłki mieszkaniowe) budzi wątpliwości istnienie solidarności wspólnoty ryzyka.

Zarysowane dynamiczne zmiany w zakresie systemów świadczeniowych stały się źródłem trudności w ich systemowym ujęciu. Podjęta w piśmiennictwie próba przyporządkowania nowych rodzajów świadczeń do „,klasycznych” ryzyk przez ich kwalifikowanie jako świadczeń należących do pomocniczej części zabezpieczenia społecznego bądź też jako specyficznych, względnie łagodniejszych, postaci „ustabilizowanych” ryzyk socjalnych nie przekonuje.

Na tym gruncie wywiązała się w piśmiennictwie dyskusja nad trafnością posługiwania się pojęciem zabezpieczenia społecznego jako obejmującego zarówno dawniej ukształtowane systemy świadczeniowe w postaci ubezpieczeń społecznych, zaopatrzenia i pomocy społecznej, jak i nowe systemy świadczeniowe $\mathrm{w}$ postaci świadczeń socjalnego wsparcia oraz świadczeń odszkodowania socjalnego. Propozycja innego ujęcia, w postaci „prawa socjalnego” spotkała się z krytyką

${ }^{32}$ Zob. R. Babińska-Górecka, K. Stopka, Stare dogmaty i nowe wyzwania w prawie ubezpieczeń społecznych, [w:] Stare dogmaty - nowe wyzwania w prawie i ekonomii, red. U. Kalina-Prasznic, Warszawa 2013.

33 J. Jończyk, Przyczynek do koncepcji... 
Podniesiony został zarzut natury językowej, że pojęcie prawa socjalnego ze względu na trudności rozróżnienia między terminami „,społeczne" oraz „socjalne" ma charakter wieloznaczny i w konsekwencji ma małą wartość operacyjną. Zarzut ten - moim zdaniem - nie przekonuje, ponieważ z równą mocą może działać w stronę przeciwną. Nie przekonuje również zarzut ideologicznego obciążenia terminu prawo socjalne, który ma łączyć się z ideologią państwa dobrobytu i teorią zaspokajania przez państwo potrzeb obywateli. Swego czasu przeciw terminowi zabezpieczenie społeczne również zgłaszano tego rodzaju zastrzeżenia, że mianowicie wyraża idee kolektywistyczne, później jednak uznano, że jest przydatny jako pojęcie zbiorcze dla urządzeń socjalnych $\mathrm{w}$ postaci, $\mathrm{w}$ jakiej wykształciły się one w latach czterdziestych XX w. oraz w latach następnych, a także w zakresie postulowanych kierunków ich rozwoju. Trzeba jednak zauważyć, że w pojęciu „zabezpieczenia społecznego" występują inne ograniczenia, mające swoje źródła w samym rozumieniu jego elementu „społeczne”. We współczesnych ujęciach ${ }^{34}$ określenie „społeczne” odnosi się zarówno do rodzaju zagrożenia dotyczącego człowieka i zagrożonej grupy osób, jak i do wspólnego wysiłku tej społeczności, podejmowanego w celu zmniejszenia tego zagrożenia i łagodzenia jego skutków „,z czym łączy się trzecia jeszcze sugestia tego przymiotnika: wspólnego interesu i solidarnego współdziałania zagrożonych osób, bez oglądania się na inne korzyści niż zabezpieczenie społeczne". Przy takim rozumieniu zabezpieczenia "społecznego" trudno objąć nim nowe systemy świadczeniowe, $\mathrm{np}$. w postaci odszkodowania socjalnego, w którym trudno dopatrywać się solidarnego współdziałania zagrożonych osób, bez oglądania się na inne korzyści niż zabezpieczenie społeczne.

Termin zabezpieczenie społeczne jest adekwatny do systemów świadczeniowych, jakie ukształtowały się w okresie po II wojnie światowej i w latach późniejszych, tj. do systemów świadczeniowych w postaci ubezpieczeń społecznych, zaopatrzenia społecznego i opieki (pomocy) społecznej. Coraz trudniej przystaje on do systemów współczesnych, znamiennych wzbogaceniem rodzajów świadczeń zabezpieczenia socjalnego. Termin prawo socjalne tymczasem pozostaje otwarty na te nowe zjawiska. Można objąć nim zarówno prawo zabezpieczenia społecznego, zawierające systemy składające się na zabezpieczenie w znaczeniu "klasycznym”, jak i regulacje prawne obejmujące nowe systemy świadczeniowe.

Warto na koniec zwrócić uwagę, że współcześnie za kryterium podziału systemu prawa na gałęzie uznaje się nie tylko przedmiot regulacji, ale również funkcję (cel) danego zespołu norm. Kryterium przedmiotu regulacji przystaje do ustabilizowanych systemów prawnych, np. do prawa

\footnotetext{
${ }^{34}$ Por. J. Jończyk, Prawo zabezpieczenia..., wyd. III, s. 9.
} 
pracy. W przypadku systemów pozostających w dynamicznym rozwoju, jak zabezpieczenie socjalne, wyznacznikiem wyróżniającym, a zarazem spajającym, jest spełnianie przez poszczególne systemy świadczeniowe tej samej funkcji, co nie oznacza, że nie ma innych wspólnych cech prawnych tych nowych systemów świadczeniowych z „klasycznymi”. W ramach niniejszego krótkiego szkicu, wykraczającego już poza wyznaczone ramy, brak miejsca na ich omówienie.

\section{Bibliografia}

Babińska-Górecka R., Funkcja pomocy społecznej, [w:] Z zagadnień prawa pracy i prawa socjalnego. Księga jubileuszowa Profesora Herberta Szurgacza, red. Z. Kubot, T. Kuczyński, Warszawa 2011.

Babińska-Górecka R., Stopka K., Stare dogmaty i nowe wyzwania w prawie ubezpieczeń społecznych, [w:] Stare dogmaty - nowe wyzwania w prawie i ekonomii, red. U. Kalina-Prasznic, Warszawa 2013.

Duch K., Ubezpieczenie społeczne, Warszawa 1934.

Jackowiak Cz., Jaśkiewicz W., Piotrowski W., Prawo pracy w zarysie, Poznań 1970 [także wyd. z 1980 r.].

Jończyk J., Prawo zabezpieczenia społecznego. Ubezpieczenia społeczne $i$ zdrowotne, bezrobocie i pomoc społeczna, Zakamycze, Kraków 2001 [zob. też wydania z 2003 i 2006 r.].

Jończyk J., Przedmiot prawa ubezpieczenia społecznego, [w:] Problemy ubezpieczenia społecznego, Wrocław 1988.

Jończyk J., Przyczynek do koncepcji prawa ubezpieczenia społecznego, [w:] Studia z prawa pracy. 50-lecie działalności naukowej Prof. Dra Wacława Szuberta, Łódź 1998.

Kaczyński L., Pojęcie zabezpieczenia społecznego i kryteria rozróżnienia jego technik, „Praca i Zabezpieczenie Społeczne" 1986, z. 5-6.

Krzeczkowski K., O trzech etapach opieki społecznej, [w:] idem, Polityka społeczna. Wybór pism $z \dot{z} y$ ciorysem i charakterystyka twórczości, Łódź 1947.

Lach D., Pojęcie zabezpieczenia społecznego a przedmiot prawa socjalnego, [w:] Problemy zatrudnienia we współczesnym ustroju pracy. Księga Jubileuszowa na 55-lecie pracy naukowej i dydaktycznej Profesora Włodzimierza Piotrowskiego, Poznań 2009.

Machnikowska M., Regulacja prawna socjalnego wsparcia dla osób o niskich dochodach, Wrocław 2013.

Okolski A., Wykład prawa administracyjnego oraz prawa administracyjnego obowiazujacego w Królestwie Polskiem, Warszawa 1882, t. II.

Piotrowski J., Zabezpieczenie społeczne. Problematyka i metody, Warszawa 1966.

Pohorille M., Spożycie zbiorowe i świadczenia społeczne, Warszawa 1975.

Stopka K., Charakter prawny zaopatrzenia z tytułu wypadków w szczególnych okolicznościach, „Państwo i Prawo” 2011, nr 9.

Stopka K., Uwagi na temat państwowej kompensaty dla ofiar przestępstw, „Państwo i Prawo” 2014, nr 7.

Stopka K., Zasada subsydiarności w pomocy społecznej, Warszawa 2009.

Szubert W., O charakterze prawnym ubezpieczenia społecznego, „Praca i Zabezpieczenie Społeczne" 1972, z. 3.

Szubert W., Ubezpieczenie społeczne. Zarys systemu, Warszawa 1987. 
Szurgacz H., Ubezpieczenia społeczne w latach okupacji hitlerowskiej 1939-1945, [w:] idem, Wstęp do prawa pomocy społecznej, Wrocław 1993.

Szurgacz H., Wstęp do prawa pomocy społecznej, Wrocław 1993.

Szurgacz H., Zakładowa działalność socjalna. Zagadnienia prawne, [w:] Zakład pracy, red. J. Jończyk, Wrocław 1977.

Zawadzki J., Zasady Opieki społecznej, Warszawa 1935.

\section{The Evolution of Social Security Services in Poland and their Legal Qualifications (an Outline of Development)}

\section{Summary}

The development of social security services in Poland proceeded in such a way that older benefits were not replaced by better new services, but instead were built in a manner that never services complement the existing ones (benefits systems). In this way, they became richer, to meet the needs created by the developments in society. Their historical development was evolutionary, while maintaining the essential characteristics of the original services.

In the legal literature various types of services were initially treated separately, belonging to different law branches. Since the 1930's they have started being grouped together under the branches of social security law. In Poland, the concept of social security law was discussed theoretically from the 1970s, and became implemented in practice from the beginning of this century. Appearance of new benefit systems, as well as changes taking place in the framework of classical benefit systems have underpinned the coherence of this concept and became a source of social law concept as a separate law branch. 